DOI:10.33099/2311-7249/2021-42-3-5-16

УДК 378.147:004.94

Олександр Васильович Майстренко (доктор військових наук)

Олександр Вікторович Лихольот

Максим Олександрович Кольченко

Національний університет оборони Украӥни імені Івана Черняховського, Київ, Украӥна

\title{
ЗАСТОСУВАННЯ МЕТОДУ ДВОХ ФУНКЦІЙ ДЛЯ ВИРІШЕННЯ ЗАВДАНЬ БОЙОВОГО ЗАБЕЗПЕЧЕННЯ РАКЕТНИХ ВІЙСЬК I АРТИЛЕРІЇ
}

Дослідження присвячене обтрунтуванню підходів щзодо розробки та впровадження програми пов'язаної із визначенням потреби у засобах метеорологічного забезпечення та повноти метеорологічної інформаиї у відповідних військових формуваннях.

У статті проаналізовано існуючі форми подачі метеорологічної інформації. Виявлено, що форми подачі такої інформачії залежать від потреб споживача, однак мають частину інформації, яка корисна для потреб військових споживачів, зокрема для потреб ракетних військ і артилерії. До такої інформацї̈ належать: температура повітря, атмосферний тиск, швидкість і напрямок вітру, вологість повітря.

Також, у роботі розроблено порядок переводу метеорологічної інформаиії отриманої з різних джерел у форму потрібну для військових формувань. Основними етапами порядку є: переведення величини атмосферного тиску; побудова графіку вертикального розподілу стандартних ізобаричних поверхонь та переведення ивього графіку з стандартних ізобаричних поверхонь до стандартних висот прийнятих в ракетних військах $i$ артилерії; побудова графіків залежності величин температури повітря, напряму та швидкості вітру від стандартних висот; перерахунок напряму та швидкості вітру в балістичні складові вітру по стандартним висотам; врахування прогнозованих величин метеоелементів; узагальнення метеорологічних та гідрологічних явищ.

До того ж, у статті розроблено методику оптимального розподілу джерел метеорологічної інформації за споживачами. Сутність методики полягає у застосуванні методу нелінійного програмування, так званого методу двох функиій, для розподілу неоднорідних, за можливостями, джерел метеоінформації між неоднорідними, за потребами, споживачів такої інформаиії. Ця методика дозволяє оперативно здійснювати розподіл наявних джерел метеоінформачї̈ між споживачами такої інформачії.

Ще у дослідженні запропонована прочедура застосування програмного засобу «Повнота метеоінформації». Ця процедура включає послідовність дій та їх змістовне наповнення щодо застосування зазначеного програмного засобу. Вказана прочедура дозволяє зменшити час на засвоєння навичок роботи з вказаним програмним засобом.

Ключові слова: метеорологічна інформачія, оптимальний розподіл, програмний засіб, підготовка військ.

\section{Вступ}

3 підвищенням рівня науково-технологічного прогресу суспільства, безумовно відбуваються зміни в усіх сферах діяльності людини. Особливо це проявляється в розвитку новітньої зброї та теорії іiі застосування. Адже 3 розвитком інформаційно-комунікаційних технологій (IКT) зміни у воєнному мистецтві відбуваються набагато частіше.

Розвиток підходів до бойового застосування військових формувань обумовлює розвиток i підходів до їх бойового забезпечення, зокрема метеорологічного. Важливість метеорологічного забезпечення в епоху високотехнологічного озброєння досить складно переоцінити. Адже неврахування метеорологічних умов, наприклад, при застосуванні ракетних військ і артилерії може призвести не тільки до невиконання бойового завдання, а і до втрат серед мирного населення та цивільної інфраструктури $[1,2]$. До того ж, відсутність достатнього обсягу метеорологічної інформації суттєво впливатиме на прийняття рішень командирами, наприклад, під час планування бою, маршу, розміщення на місці.

Постановка проблеми. Таким чином, розвиток IКТ пов'язаних 3 метеорологічним забезпеченням $\epsilon$ важливим, як для практики бойового застосування військ, так i для їх підготовки. Причому питання метеорологічного забезпечення враховуються як при плануванні бою (тактичний рівень), так і при плануванні операцій (оперативний та стратегічний рівні). 
Одним із важливих питань щодо метеорологічного забезпечення військ $\epsilon$ визначення обсягу метеорологічної інформації та іiі придатності для вирішення специфічних бойових завдань. Іншими словами, однією із найбільш важливих, $\epsilon$ така властивість метеорологічного забезпечення, як повнота метеорологічної інформації. У даному випадку під повнотою розуміється кількість джерел, які здатні забезпечити відповідною до бойових завдань метеорологічною інформацією.

Суттєвою проблемою є відсутність такого програмного засобу, який би задовольняв потреби командирів та штабів під час організації метеорологічного забезпечення.

Актуальність цього дослідження підтверджується появою нових зразків озброєння, зокрема таких як комплекс радіозондування багатофункціональний Радіотеодоліт-УЛ [3].

Також актуальність розробки та впровадження у процес підготовки та бойового застосування військ програмного забезпечення пов'язаного із метеорологічним забезпеченням обумовлюється впровадженням автоматизованих систем підтримки та прийняття рішень командирами, таких як Milchat, Оболонь, СУВА [4, 5].

До того ж, актуальність проведення такого дослідження визначається розширенням спектру метеорологічної інформації, використанням різних форм подачі метеорологічної інформації, появою різних джерел такої інформації. [6, 7].

Таким чином, розроблення та впровадження у процес підготовки та бойового використання програмного забезпечення для визначення повноти метеорологічної інформації $€$ актуальним науковим завданням.

Аналіз останніх досліджень і публікацій. Дисертація [8] спрямована на вирішення актуальної наукової проблеми створення методології удосконаленого метеорологічного забезпечення аеронавігації за рахунок розвитку та використання поляриметричних засобів оперативного виявлення небезпечних для польотів динамічних явищ та розповсюдження метеорологічної інформації усім зацікавленим учасникам повітряного руху. Однак у дисертації не врахована така властивість як повнота метеоінформації для сукупності різнотипових споживачів.

У статті [9] розглядаються можливості використання оглядових РЛС сантиметрового діапазону хвиль, які перебувають на озброєнні радіотехнічних військ, для ведення метеорологічної розвідки з метою забезпечення авіації Повітряних Сил Збройних Сил України метеорологічною інформацією. Аналізуються потенційні та реальні можливості означеного класу радіолокаційних засобів щодо ведення радіолокаційної розвідки погодних явищ. Розглядаються можливі напрямки модернізації оглядових РЛС сантиметрового діапазону хвиль як засобів метеорологічної розвідки. Однак у статті не розглянута можливість забезпечення отриманою метеоінформацією інші складові Збройних Сил України.
У статті [10] розглядається конкретизація компетенцій фахівців зайнятих в області метеорологічного забезпечення. Запропоновано в якості мети в сучасній освіті таких фахівців розглядати формування у фахівця відповідних його профілю компетенцій. Однак у статті не розглянуто вплив на розвиток компетенцій застосування засобів IКТ.

У статті [11] Розглянуто можливості підвищення інформаційного забезпечення користувачів метеорологічною інформацією за рахунок використання комплексної глобальної системи отримання та розповсюдження метеорологічних даних. Запропоновано структурну схему комплексної глобальної інтерактивної системи отримання, обміну, поширення та використання метеорологічної інформації, що доповнена зв'язками, які дозволяють у критичний момент польоту акцентувати увагу на найбільш небезпечних метеорологічних явищах за маршрутом польоту. Однак у статті розглянуті можливості комплексування джерел мтеоінформації лише в інтересах авіації.

У статті [12] розглянуто перспективні напрямки розвитку технічних засобів для одержання більш надійної, достовірної та деталізованої інформації стосовно метеоумов за маршрутом польоту для ефективної роботи глобальної мережі одержання та розповсюдження інформації. Розроблено структурну схему глобальної мережі. Особливу увагу приділено використанню повітряних кораблів як динамічних елементів для одержання та обміну метеорологічними даними. Однак не розглянуто таку властивість, як повнота метоінформації.

У статті [13] проведена оцінка точності урахування метеорологічних факторів при стрільбі артилерії на великі дальності, досліджені умови забезпечення повної підготовки стрільби, наведено приклад розрахунку серединних помилок у дальності i напрямку для конкретних артилерійських систем. Однак у статті не визначено яку саме кількість та який вид метеоінформації необхідно отримати для гарантованого виконання бойових завдань.

У навчальному посібнику [14] висвітлено питання організації і проведення математичного та комп'ютерного моделювання систем аеронавігаційного обслуговування, їх складових елементів, а також моделювання інформаційних процесів та прийняття рішень у системі керування повітряним рухом. Наведено методи дослідження та оцінювання характеристик системи повітряного руху. Для студентів спеціальностей “Системи аеронавігаційного обслуговування" та “Обслуговування повітряного руху”. Однак у посібнику не розглянуто особливості підготовки військових фахівців.

У статті [15] визначено сучасний стан радіолокаційної складової існуючої мережі спеціалізованих засобів метеорологічного обслуговування авіації, що містить імпульсні доплерівські метеорологічні радіолокатори та аеродромні радіолокаційні комплекси 3 каналами обробки відбиттів від метеоутворень. Надано 
розрахунки радіолокаційного поля, що створюється цією мережею. Показано, що вона не забезпечує потрібне суцільне радіолокаційне покриття на усіх заданих висотах. Обгрунтовано пропозиції щодо створення суцільного метеорологічного радіолокаційного поля на основі перспективної мережі метеорологічних радіолокаційних засобів, в яку до існуючого парку імпульсних доплерівських метеорологічних радіолокаторів долучені радіолокаційні засоби сантиметрового діапазону із каналами обробки метеосигналів. Надано розрахунки радіолокаційного поля, що створюється запропонованою мережею метеорологічних радіолокаційних засобів. Однак у статті не розглянута здатність запропонованої мережі забезпечувати метеоінформацією споживачів із різними потребами такої інформації.

У роботі [16] розглянуто особливості функціонування та побудови метеорологічних систем 3 метою розробки для них програмного забезпечення. Розглянуто три структури метеосистем: глобальні - об'єднання метеостанцій у національні та міжнародні мережі для прогнозування погоди на великих територіях, локальні системи - для визначення умов на певних ділянках (у районі аеродрому, бурової платформи та ін.) та метеостанції - сукупність приладів для метеорологічних вимірювань (спостережень за погодою). Визначено, що для обслуговування та управління глобальними системами може бути використане програмне забезпечення типу SCADA-систем. На основі проведеного аналізу запропоновано та описано структуру спеціалізованого програмного забезпечення для збирання, обробки, відображення та реєстрації даних моніторингу метеостанцій та локальних метеорологічних систем на їх основі, яке дозволяє проводити моніторинг метеорологічного обладнання, налаштування конфігурації системи збирання даних та провадити необхідну обробку інформації. Однак у роботі не окреслено можливості створення програмного забезпечення щодо визначення повноти метеоінформації для військових споживачів.

У статті [17] на підставі відпрацьованого великого обсягу метеоінформації, яка надходить до метеослужби у різні періоди часу, проведено аналіз досвіду метеорологічного забезпечення польотів авіації різних рівнів, запропоновано опрацювання прогностичних даних та розроблені рекомендації для чергового метеоролога щодо метеорологічного забезпечення польотів авіації 3 використанням автоматизованого робочого місця синоптика. Однак у статті не розглянуто можливість організації метеорологічного забезпечення у цілому для Збройних Сил України.

У статті [18] проведено аналіз досвіду метеорологічного забезпечення польотів авіації; запропоновано інструмент опрацювання прогностичних даних та розробки рекомендацій для чергового метеоролога щодо метеорологічного забезпечення польотів авіації Збройних Сил України. Однак у цій статті не розглянуто можливість забезпечення метеоінформацією інші складові Збройних Сил України окрім авіації.
Винахід [19] належить до радіолокаційної метеорології, а саме до радіоакустичних способів вимірювання метеорологічних величин атмосфери, i може бути використаний при складанні короткострокових прогнозів погоди, при метеорологічному забезпеченні екологічного моніторингу атмосфери та безпеки зльоту i посадки літальних апаратів різного призначення, при складанні радіокліматичних карт, у дослідженнях 3 фізики атмосфери і таке інше. Однак у описі цього винаходу не вказано його придатність до отримання метеоінформації в інтересах різнотипових споживачів такої інформації.

У статті [19] виконане проектування високорівневих алгебро-алгоритмічних специфікацій паралельної програми, призначеної для розв'язання задачі метеорологічного прогнозування. На основі побудованих специфікацій здійснена генерація програмного коду із використанням інструментарію автоматизованого проектування й синтезу програм. Проведено експеримент 3 виконання розробленої паралельної програми на багатоядерній платформі. Однак у статті не розглянуто можливість використання метеоінформації із різнотипових джерел.

Загалом в означених дослідженнях зроблено суттєвий внесок у розвиток і впровадження IКT, пов'язаних із метеорологічним забезпеченням, як в освітній процес ЗВО, так і в практику бойового застосування військ. Однак залишається не вирішеним питання щодо розробки та впровадження IKT пов'язаної із визначенням потреби у засобах метеорологічного забезпечення та повноти метеорологічної інформації.

Мета статті - обгрунтування підходів щодо розробки та впровадження ІКТ повязаної із визначенням потреби у засобах метеорологічного забезпечення ракетних військ і артилерії та їх оптимального розподілу між споживачами.

\section{Виклад основного матеріалу дослідження}

Зважаючи на відсутність певних елементів процедури відбору та оцінювання ефективності функціонування нових IКТ в дослідженні частково використані напрацювання 3 попередніх досліджень [4, 20], а також загальновідомий науково-методичний апарат [21-23].

Загалом етапами дослідження прийнято:

аналіз існуючих форм подачі метеорологічної інформації;

розроблення порядку переводу метеорологічної інформації у форму потрібну для військових формувань;

розроблення методики оптимального розподілу джерел метеорологічної інформації за споживачами;

визначення процедури застосування програмного засобу “Повнота метеоінформації”.

Стосовно науково-методичного апарату у дослідженні застосовані такі методи:

аналізу, для визначення особливостей метеорологічної інформації отриманої 3 різних джерел; 
двох функцій методів нелінійного програмування, для проведення оптимального розподілу джерел метеорологіної інформації відповідно до особливостей метеорологічної інформації отриманої з різних джерел та потреби у певному типові цієї інформації.

Зважаючи на загальновідому сутність означених наукових методів пропонується коротко окреслити методи аналізу та методу двох функцій.

Сутність методу аналізу полягає у розкладанні цілого на складові частини у результаті процесу розумової або фактичної діяльності [22].

Сутність методу двох функцій полягає у розподілі неоднорідних ресурсів між неоднорідними споживачами шляхом визначення виграшу з урахування можливого програшу у разі не призначення [21-23].

Враховуючи значущу роль ракетних військ i артилерії (РВіA) у сучасних військових конфліктах, а також суттєву залежність ефективності РВіА від метеорологічної інформації, дослідження пропонується проводити на фоні застосування РBiA.

Зміст методу двох функцій полягає в знаходженні такої матриці $\left\|\vartheta^{0}\right\|$, яка б максимізувала функцію придатності джерел метеоінформації споживачам цієї інформації (F) [21-23].

$$
\mathrm{F}=\sum_{\gamma=1}^{\mathrm{S}} \Theta_{\gamma}\left(1-\prod_{\mathrm{j}=1}^{\mathrm{N}}\left(1-\omega_{\gamma \mathrm{j}}\right)\right),
$$

де, $\gamma$ - індикатор номера споживача;

$\mathrm{S}$ - кількість споживачів;

$\Theta$ - коефіцієнт важливості певного споживача;

j - індикатор номера джерела метеоінформації певного типу;

$\mathrm{N}$ - кількість джерел метеоінформації певного типу;

$\omega$ - імовірність забезпечення споживача метеоінформацією.

При обмеженнях коли на одному кроці проводиться призначення одного джерела на одного споживача та індикатор номера споживача набуває значень від 1 до $N$.

$$
\sum_{\gamma=1}^{\mathrm{S}} \vartheta_{\mathrm{j} \gamma}=1, \mathrm{j}=1 \ldots . \mathrm{N} .
$$

За таких додаткових умов: складові матриці набувають значень 1 або 0 , імовірність не забезпечення споживача лежить у межах від 0 до 1, коефіцієнт важливості цілі більше 0.

$$
\left.\begin{array}{c}
\vartheta_{\mathrm{j} \gamma} \in\{1,0\}, \\
\Theta_{\gamma}>0 .
\end{array}\right\} \begin{aligned}
& \mathrm{j}=1 \ldots \mathrm{N}, \\
& \gamma=1 . . . \mathrm{S} .
\end{aligned}
$$

Характерною особливістю методу двох функцій $\epsilon$ те, що характеристики, які описують забезпечення метеоінформацією певного споживача певним джерелом, характеризується своєю імовірністю забезпечення $\left\{\omega_{\mathrm{j} \gamma}\right\}_{\mathrm{S}}$, заданою у матриці $\left\|\omega_{\mathrm{j \gamma}}\right\|_{\mathrm{NS}}[21-23]$. Відповідно, рішення про призначення певного типу джерела повинно бути прийняте до виконання по кожному споживачеві. Для цього кожному типу джерела присвоюється номер $\mathrm{j}(\mathrm{j}=1 \ldots \mathrm{N})$, а факт призначення певного типу джерела для забезпечення споживача метеоінформацією фіксується індикатором $\vartheta_{\mathrm{j} \gamma}=1 \quad\left(\vartheta_{\mathrm{j} \gamma}=0-\right.$ в іншому випадку). За таких умов матриця, буде включати в себе відомості про закріплення кожного джерела метеоінформації за кожним споживачем цієї інформації.

Таким чином, даний підхід базується на розподілі неоднорідних типів джерел метеоінформації між споживачами такої інформації.

Аналіз останніх воєнних конфліктів [24-29] свідчить, що зростання швидкості ведення бойових дій призводить до зростання обсягу різнорідної інформації, яка циркулює в каналах зв'язку та передачі даних. Звичайно інформація може бути як корисною так і такою, що не несе корисного змісту, але має місце тому, що іiі, як правило, формалізують за певним алгоритмом. В той же час, із збільшенням обсягу інформації збільшується імовірність втрати ії змісту через перевантаження каналів. Однією 3 складових загального обсягу інформації $\epsilon$ метеорологічна інформація для РВіА. Метеорологічну інформацію для РВіА прийнято формалізувати в бюлетень «Метеосередній» зміст якого, як правило, не залежить від завдань вогневого ураження противника (ВУП), які покладаються на РВіА [30]. Тому бюлетень несе частину непотрібної інформації, що зменшує ефективність каналів зв'язку та передачі даних, використання сил i засобів для метеозабезпечення бойового застосування РВіА, а також призводить до втрати управління ними.

Відомо, що для застосування різних видів артилерії, а також деяких видів боєприпасів необхідна специфічна метеоінформація. Так, наприклад, для реактивної артилерії важливими $є$ складові балістичного вітру в районі цілей, для нарізної артилерії, яка використовує високоточні боєприпаси - висота нижньої межі хмар, швидкість середнього вітру на ділянці наведення керованого (коректованого снаряду), метеорологічна дальність видимості. Виходячи 3 цього, споживачів метеоінформації пропонується розподілити за категоріями - підрозділи реактивної артилерії, підрозділи нарізної артилерії та мінометів та підрозділи нарізної артилерії, які застосовують високоточні боєприпаси.

3 іншого боку різні за видом джерела інформації дають різну за об'ємом та корисністю для РВіА метеорологічну інформацію. Так, станції Гідрометцентру України через їх офіційні інтернет-сайти надають інформацію щодо метеорологічних умов та величин метеорологічних елементів на території країни (КН-04) [31]. Авіаційні метеорологічні станції надають інформацію, щодо метеорологічних умов на відстані курсування повітряних суден, величин метеорологічних елементів в приземному шарі в межах аеродрому (METAR, SPECI) [32] та у виняткових випадках у вигляді бюлетеня 
«Метеосередній». Але існує декілька перешкод для прямого використання інформації наданої Гідрометцентром України та авіаційними метеорологічними станціями, по-перше використання при розробці карт погоди стандартних ізобаричних висот, що потребує проведення перерахунку для використання в $\mathrm{PBiA}$. Виходячи 3 цього, основними джерелами метеоінформації, яку доречно використовувати в інтересах PBiA пропонується вважати такі: метеорологічні станції $\mathrm{PBiA}, \quad$ станції Гідрометцентру України та авіаційні метеорологічні станції.

Для передачі результатів метеорологічних i аерологічних спостережень метеорологічна інформація кодується у вигляді зведень і телеграм. Закодовані телеграми складаються зазвичай 3 п'ятизначних цифрових груп. Кожній метеорологічній величині або явищу в групі відведено постійне місце, порядок груп в телеграмі суворо визначений.

Смислові значення чисел, вживаних для кодування кожної метеорологічної величини і явища, розшифровуються за допомогою таблиць i пояснень, що містяться у відповідних кодах.

Код для передачі даних метеорологічних спостережень 3 наземних і морських станцій, КН01 (міжнародна форма FM 12-VII SINOP і FM 13VII SHIP) [33].

У цьому коді для зручності машинної обробки інформації групи, що підлягають глобальному, регіональному і національному обмінам, об'єднані в розділи із спеціальними пізнавальними цифрами. Крім того, для підвищення точності означених даних в коді передбачена можливість передачі додаткових цифр для температури повітря, точки роси, тиску, баричної тенденції, кількості опадів, зведення про минулу погоду, висоти сніжного покриву; введені нові таблиці для кодування стану поверхні грунту, уточнені таблиці для кодування хмар. Розділи кодів 0, 1, 2 повністю відповідають міжнародній кодовій формі FM 12-VII і FM 13-VII, розділи 3, 4 і 5 є національним варіантом цієї кодової форми.

Код для складання гідрометеорологічних радіограм на судах, KH-Olc (скорочений варіант єдиного коду КН-01; міжнародна форма FM 13-VII SHIP) [33].

Код для передачі даних вітрового зондування атмосфери, КН-03 (повністю відповідає міжнародним кодовим формам FM 32-V PILOT i FM 33-V PILOT SHIP, що передбачає строгу стандартизацію змісту i способу кодування інформації 3 метою обробки іiі за допомогою електронно-обчислювальних машин) [34].

Код для передачі даних вертикального зондування атмосфери, КН-04 (FM 35-V TEMP, FM 36-V TEMP SHIP) [31].

Код для передачі даних спостережень метеорологічних радіолокаторів (міжнародна форма FM 20-V RADOB). Цей код складається 3 двох частин: A - для передачі інформації про тропічні циклони, В - для передачі даних про хмари і пов'язані 3 ними явища (включає три розділи: міжнародний, регіональний i національний) [34].
Коди для передачі даних спостережень 3 штучних супутників Землі.

Цими кодами зашифровується наступна інформація:

дані про вітер, приземну температуру, хмарність, вологість і радіацію (FM 88-VI SATOB);

дані аерологічного зондування (тиск, температура i вологість повітря) (FM 86-VI SATEM);

дані про радіацію, що йде, при ясному небі (FM 87-VI SARAD).

При використанні інформації 3 штучних супутників землі необхідно пам'ятати про те, що вона містить помилки як безпосередніх вимірювань, так i методичних розрахунків, i звертати увагу на показники точності.

Міжнародні авіаційні коди [34]. Ці коди застосовуються:

для передачі стану погоди на аеродромі (регулярне повідомлення) (FM 15-V METAR);

для передачі повідомлень про істотні зміни погоди на аеродромі (вибіркове спеціальне повідомлення) (FM 16-V SPECI);

для прогнозу вітру і температури на висотах в певних точках (FM 48-V ARMET); TAP);

для прогнозу погоди по аеродрому (FM 51-V

для авіаційного прогнозу погоди по території (FM 53-V ARFOR);

для авіаційного прогнозу погоди по маршруту (FM 54-V ROFOR).

Код для передачі консультацій по картах погоди, КП-53.

Код для передачі прогнозів судам, КП-55.

Код фактичної погоди на аеродромі (ФАП).

Код для передачі прогнозів погоди по аеродрому (АПП).

Звичайно кожен із означених кодів несе певне інформаційне навантаження та певним чином відповідає цілям метеозабезпечення РВіА. Аналіз означених метеорологічних кодів свідчить, що найбільше відповідної цілям метеозабезпечення РВіА інформації включають: код для передачі даних метеорологічних спостережень з наземних $\mathrm{i}$ морських станцій КН-01; код для передачі даних вертикального зондування атмосфери КН-04 та міжнародний авіаційний код для передачі стану погоди на аеродромі (METAR).

Зважаючи на розподіл артилерії та боєприпасів за категоріями та об'єм метеорологічної інформації в метеорологічних кодах КН-01, КН-04, METAR (SPECI) можливо підвищити повноту метеорологічної інформації за рахунок використання метеоінформації 3 джерел, які не належать до РВіА.

Звичайно використання метеорологічної інформації від означених джерел, табл. 1, без приведення до формалізації прийнятої в $\mathrm{PBiA}$ викличе суттєві ускладнення. Тому пропонується розглянути порядок переведення метеорологічної інформації отриманої від джерел, які не належать до РВiА у вигляд прийнятий в $\mathrm{PBiA}$.

Зважаючи на те, що у кодах КН-01, КН-04, METAR (SPECI) прийнято прив'язуватись до стандартних ізобаричних поверхонь та 
використовують величину атмосферного тиску в мілібарах (Мб) першим пунктом означеного порядку прийнято переведення величини атмосферного тиску в міліметри ртутного стовпчика (мм рт. ст.).

В подальшому, на підставі отриманих результатів, проводиться побудова графіку вертикального розподілу стандартних ізобаричних поверхонь.

Наступним пунктом означеного порядку прийнято переведення графіку 3 стандартних ізобаричних поверхонь до стандартних висот прийнятих в $\mathrm{PBiA.}$

В подальшому побудова графіків залежності величин температури повітря, напряму та швидкості вітру від стандартних висот.

Таблиця 1

Таблиця розшифровки метеорологічного коду КН-04

\begin{tabular}{|c|c|c|c|c|c|}
\hline $\begin{array}{c}\text { Атмосферний } \\
\text { тиск, R (Мб) }\end{array}$ & $\begin{array}{c}\text { Висота від } \\
\text { фактичної } \\
\text { поверхні, H (м) }\end{array}$ & $\begin{array}{c}\text { Відносна } \\
\text { температура } \\
\text { повітря, Т } \\
\left({ }^{\circ} \mathrm{C}\right)\end{array}$ & $\begin{array}{c}\text { Температура } \\
\text { повітря, } \\
\left.\text { Д( }{ }^{\circ} \mathrm{C}\right)\end{array}$ & $\begin{array}{c}\text { Напрямок } \\
\text { вітру, dd } \\
\left({ }^{\circ}\right)\end{array}$ & $\begin{array}{c}\text { Швидкість } \\
\text { вітру, ff } \\
(\text { м/с) }\end{array}$ \\
\hline 1020 & 0 & $-21,3$ & 2,4 & 250 & 2 \\
\hline 1000 & 217 & $-17,5$ & 1,9 & 270 & 8 \\
\hline 925 & 680 & $-20,5$ & 1,9 & 300 & 8 \\
\hline 850 & 1460 & $-11,7$ & 9 & 290 & 8 \\
\hline 700 & 2936 & $-17,7$ & 14 & 300 & 12 \\
\hline 500 & 5400 & $-31,3$ & 13 & 300 & 20 \\
\hline 400 & 6940 & $-42,7$ & 9 & 315 & 24 \\
\hline 300 & 8810 & $-57,7$ & 6 & 320 & 26 \\
\hline 250 & 9940 & $-67,5$ & 5 & 330 & 25 \\
\hline 200 & 11260 & $-74,5$ & 4,3 & 330 & 23 \\
\hline 150 & 12950 & $-71,7$ & 4,5 & 330 & 20 \\
\hline 100 & 15350 & $-74,1$ & 4,7 & 320 & 22 \\
\hline
\end{tabular}

Наступним пунктом є перерахунок напряму та швидкості вітру в балістичні складові вітру по стандартним висотам. Визначення пропонується проводити за наступним порядком: визначення різниці кутів $\mathrm{A}_{\mathrm{W}}=\varphi_{ц}-\varphi_{\mathrm{W}}$, де $\mathrm{A}_{\mathrm{W}}-$ різниця кутів; $\varphi_{ц} \quad-$ дирекційний кут на ціль; $\varphi_{\mathrm{W}} \quad-$ дирекційний кут вітру;

Визначення повздовжньої $\left(\mathrm{W}_{\text {бх }}\right)$ та бокової $\left(\mathrm{W}_{\text {бz }}\right)$ складових балістичного вітру за формулами:

$$
\mathrm{W}_{\text {бx }}=\mathrm{W} \cos \mathrm{A}_{\mathrm{w}} \text { та } \mathrm{W}_{\text {бz }}=\mathrm{W} \sin \mathrm{A}_{\mathrm{w}}
$$

де $\mathrm{W}$ - швидкість вітру, м/c.

Наступним пунктом $є$ облік додаткової інформації яка необхідна для РВіА, але відсутній іiі формалізований запис. Наприклад така, як (висота нижнього порогу хмар, напрям та швидкість вітру в районі цілей, щільність повітря, прозорість атмосфери)

А також додатковим пунктом необхідно включити врахування прогнозованих величин метеоелементів які $є$ обов'язковими пунктами в кодах КН-01, КН-04, METAR (SPECI).

В послідуючому необхідно узагальнити метеорологічні та гідрологічні явища, неврахування яких може призвести до зменшення ефективності М3 $\mathrm{PBiA,} \mathrm{a} \mathrm{як} \mathrm{наслідок} \mathrm{i}$ ефективність ВУП.

Загальний вигляд порядку переведення метеорологічної інформації отриманої від джерел, які не належать до PBiA у вигляд прийнятий в PВіА наведений на рис. 1.

Порядок проведення розрахунків при використанні методу двох функцій складається 3 декількох послідовних кроків.
Перший крок - обчислення часток вагових коефіцієнтів споживачів:

$$
\mathrm{R}_{\gamma}^{(\mathrm{t})}=\frac{\Theta_{\gamma}^{(\mathrm{t})}}{\sum_{\gamma=1}^{1} \Theta_{\gamma}^{(\mathrm{t})}},
$$

де, $\mathrm{R}_{\gamma}^{(\mathrm{t})}$ - частка вагового коефіцієнту $\gamma$-того споживача;

$\Theta_{\gamma}^{(\mathrm{t})}$ - ваговий коефіцієнт $\gamma$-того споживача на $\mathrm{t}$ тому кроці обчислень

1 - загальна кількість типів споживачів.

Другий крок - визначення елементів поточної матриці відповідності отриманого виграшу у разі призначення та урахуванням програшу у разі не призначення $\|\Delta\|[$ [21-23].

$$
\Delta_{\mathrm{kl}}^{(\mathrm{t})}=\mathrm{R}_{1}^{\mathrm{t}-1} \omega_{\mathrm{kl}}-\sum_{\gamma \neq 1} \frac{\mathrm{R}_{\gamma}^{(\mathrm{t}-1)} \omega_{\mathrm{k}^{\gamma}}}{\varepsilon_{\mathrm{k}} \mathrm{a}_{\gamma}^{(\mathrm{t}-1)},}
$$

При

що $\mathrm{R}_{1}^{(0)}=\mathrm{R}_{1}, \quad \mathrm{a}_{\gamma}^{0}=\prod_{\mathrm{j}=1}^{\mathrm{N}} \varepsilon_{\mathrm{j} \gamma}, \quad \gamma, 1=1 \ldots \mathrm{S}$, умовах, $\mathrm{k} \in \mathrm{N}^{(\mathrm{t})}, \quad 1=1 \ldots \mathrm{S}$

де, $\mathrm{N}^{(\mathrm{t})}-$ множина номерів джерел, невикористаних до $\mathrm{t}$-того кроку обчислень;

$\omega_{\mathrm{kl}}$ - імовірність забезпечення певного типу споживача певним джерелом;

$\varepsilon_{\mathrm{j \gamma}}-$ імовірність не забезпечення певного типу споживача певним джерелом. 


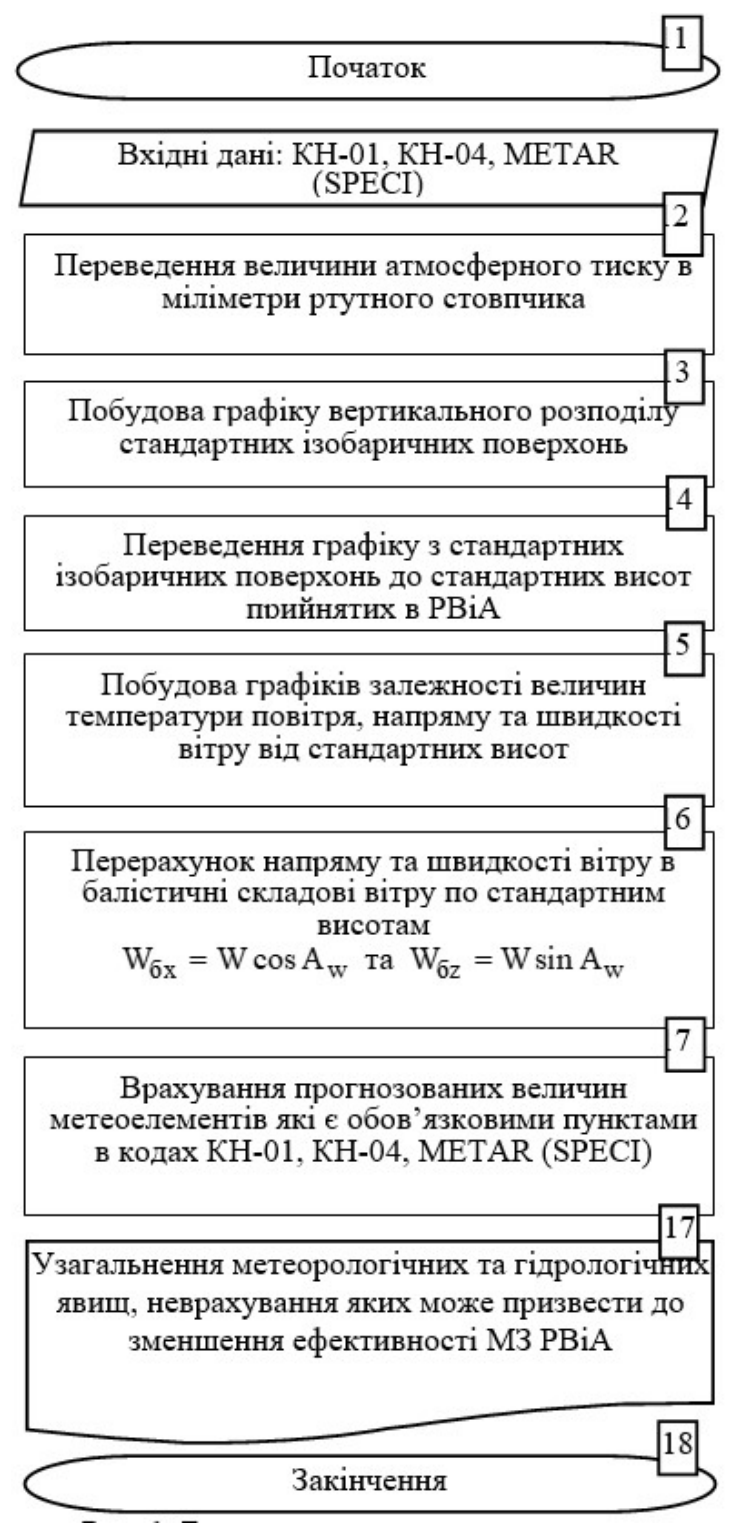

Рис. 1. Блок-схема порядку переведення метеорологічної інформації отриманої від джерел, які не належать до РВіА у вигляд прийнятий в PBiA

Третій крок - закріплення $\mathrm{k}_{\mathrm{t}}^{(\mathrm{j})}$-того джерела $\mathrm{j}$ того типу за $1_{t}$-тим видом споживача метеоінформації $\left(\vartheta_{\mathrm{k}_{\mathrm{t}} \mathrm{l}_{\mathrm{t}}}=1\right)$ відповідно до умови $\Delta_{\mathrm{k}_{\mathrm{t}} \mathrm{l}_{\mathrm{t}}}=\max _{\mathrm{k}, \mathrm{l}} \Delta_{\mathrm{kl}}, \quad \mathrm{k}^{(\mathrm{j})} \in \mathrm{N}_{\mathrm{cyM}}^{(\mathrm{t})}, \quad 1=1, \ldots, \mathrm{S}$

Четвертий крок - обчислення поточного значення цільової функції $\mathrm{F}_{\mathrm{t}}^{+}$[21-23]:

$$
\mathrm{F}_{\mathrm{t}}^{+}=\mathrm{F}_{\mathrm{t}-1}^{+}+\Delta \mathrm{F}_{\mathrm{k}_{\mathrm{t}} \mathrm{l}_{\mathrm{t}}},
$$

де, $\mathrm{F}_{0}^{+}=0$.

П’ятий крок - обчислення нових значень величин $\mathrm{R}^{(\mathrm{t})}$ i $\mathrm{a}_{\gamma}^{(\mathrm{t})}[21-23]$ :

$$
\mathrm{R}_{1}^{(\mathrm{t})}=\left\{\begin{array}{ccc}
\mathrm{R}_{1}^{(\mathrm{t}-1)}, & \text { якщо } & 1 \neq 1_{\mathrm{t}}, \\
\mathrm{R}_{1}^{(\mathrm{t}-1)} \varepsilon_{\mathrm{k}_{\mathrm{t}}}, & \text { якщо } \quad 1=\mathrm{l}_{\mathrm{t}},
\end{array}\right.
$$

$$
\mathrm{a}_{\gamma}^{(\mathrm{t})}=\frac{\mathrm{a}_{\gamma}^{(\mathrm{t}-1)}}{\varepsilon_{\mathrm{k}_{\mathrm{t} \gamma}}},
$$

На шостому кроці проводиться перевірка умови використання джерел надання метеорологічної інформації: $\mathrm{t} \leq \mathrm{N}_{\text {сум }}^{(\mathrm{t})}$, якщо умова виконується то проводяться розрахунки для наступного кроку. Якщо умова не виконується, то фіксується результати обчислень значення цільової функції $\mathrm{F}\left(\vartheta_{0}\right)=\mathrm{F}_{\mathrm{N}}^{+}$та створюється матриця призначень $\left\|\vartheta_{\mathrm{j} \gamma}^{0}\right\|_{\mathrm{NS}}$.

Алгоритм оптимального розподілу джерел метеорологічної інформації за споживачами показаний на рис. 2.

Для впровадження даного підходу (рис. 2) у процес підготовки та практику військ розроблено програмний засіб «Повнота метеоінформації». Сутність означеного програмного засобу полягає у визначенні необхідної кількості метеостанцій по типам метеорологічних кодів, які використовуються для визначення прогнозованого ступеня забезпечення метеорологічною інформацією.

Програмний засіб «Повнота метеоінформації» може застосовуватися під час підготовки та бойового застосування відповідними органами військового управління зокрема щодо порядку планування метеорологічного забезпечення.

Особливістю цього програмного засобу є його простота застосування та зрозумілість інтерфейсу. Також до переваг цього програмного засобу можна віднести швидкість проведення розрахунків.

Загальний порядок роботи 3 програмним засобом «Повнота метеоінформації» показаний на рис. 3-5.

Першим кроком роботи 3 цим програмним засобом $\epsilon-$ дати команду на виконання (відкрити) з будь-якого файлового менеджера файл «повнота метеоінформації.ехе».

Наступний крок: введення данних у поле «Вхідні дані» (рис. 3), а саме заповнити вікна «важливість споживача» - вводяться числа, які характеризують важливість деякого виду артилерії, для конкретної ситуації. Якщо споживачів 5 заповнюються всі вікна, якщо менше заповнюються вікна по кількості споживачів, решта вікон залишаються без змін (за замовчуванням 0).

Наступним кроком $\epsilon$ заповнення вікна «кількість» у блоці «джерела метеоінформації» (рис. 3). У кожне вікно у відповідності до кількості типів (метеостанції РBiA, Гідрометцентру України, авіації, морські та інші) вводиться відповідна кількість джерел метеоінформації, якщо типів джерел менше 5 незаповнені вікна залишаються без змін (по умовчанню 0).

Надалі заповнюються вікна «імовірність забезпечення джерелом споживача» (рис. 4). У вікно, яке знаходиться на перетині уявних ліній між споживачем і джерелом виставляється число (від 0 до 1), яке відповідає імовірності забезпечення вибраним джерелом метеоінформації вибраного споживача. 


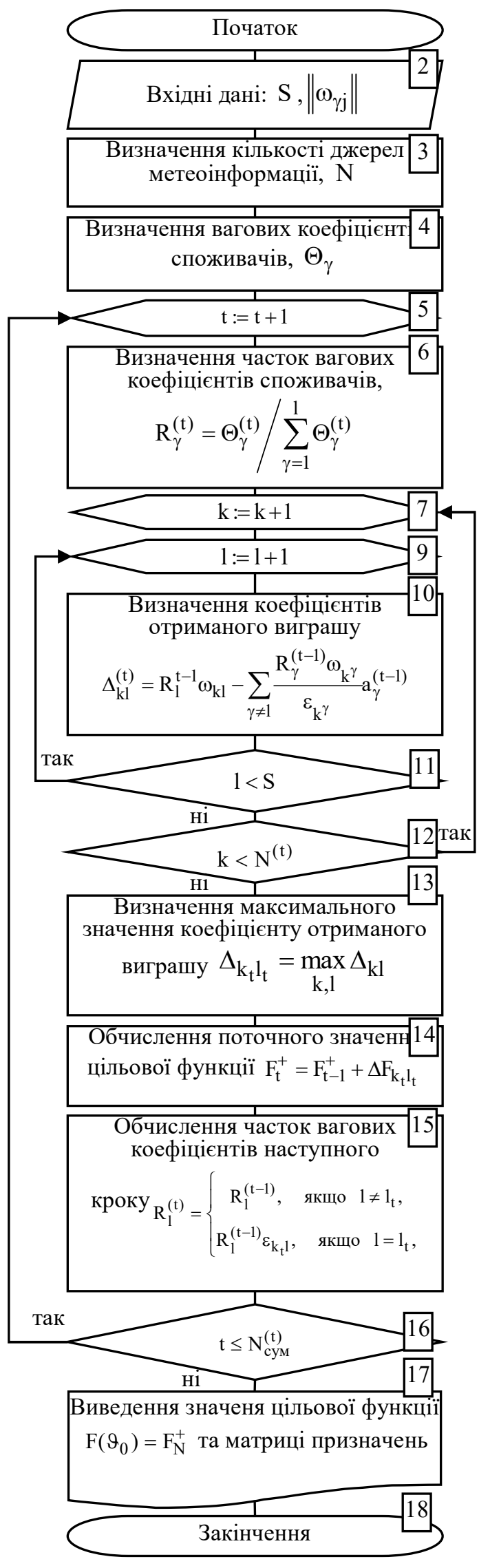

Рис. 2 Алгоритм оптимального розподілу джерел метеорологічної інформації за споживачами

Початок роботи програмного засобу відбувається після натискання кнопки «Крок»

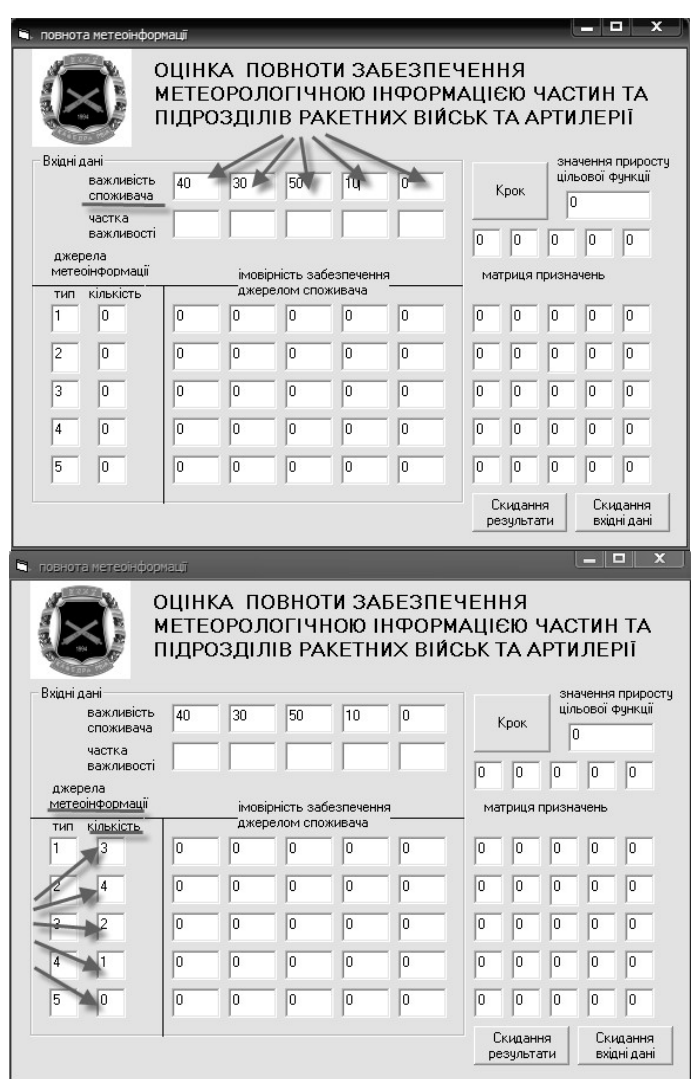

Рис. 3 Введення початкових вхідних даних до програми «Повнота метеоінформації»

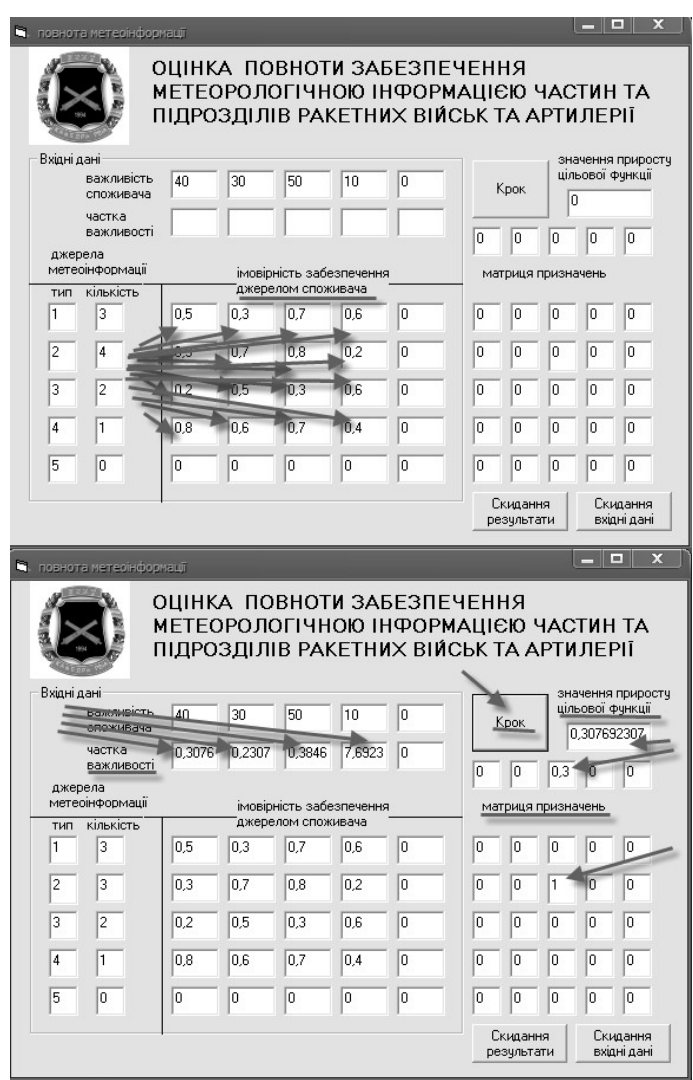

Рис. 4 Початок роботи 3 програмою «Повнота метоінформації»

(рис. 4). У вікнах «Значення приросту цільової функції» 3'явиться число, яке відповідає ступеню 
забезпеченості метеорологічною інформацією на першому кроці. У вікнах «Частка важливості» 3'явиться частка важливості конкретного споживача в загальній сукупності споживачів. У вікнах «матриця призначень» на перетині уявної лінії між обраним джерелом та споживачем які відповідають оптимальному призначенню замість 0 з'явиться 1.

Надалі необхідно повторювати натискання кнопки «Крок» до тих пір доки не закінчаться джерела (у вікнах «джерела метеоінформації кількість» буде 0), або у вікні «Значення приросту цільової функції» не з'явиться число, яке буде відповідати визначеному ступеню забезпеченості метеорологічною інформацією. У вікнах «Частка важливості» з'явиться частка важливості конкретного споживача в загальній сукупності споживачів, яка залишилась після впливу на попередніх кроках. $\mathrm{y}$ вікнах «матриця призначень» (рис. 5) на відповідних перетинах уявних ліній між обраними джерелами та споживачами, які відповідають оптимальному призначенню, з'явиться відповідне число, яке буде відповідати кількості джерел залучених для забезпечення конкретних споживачів.

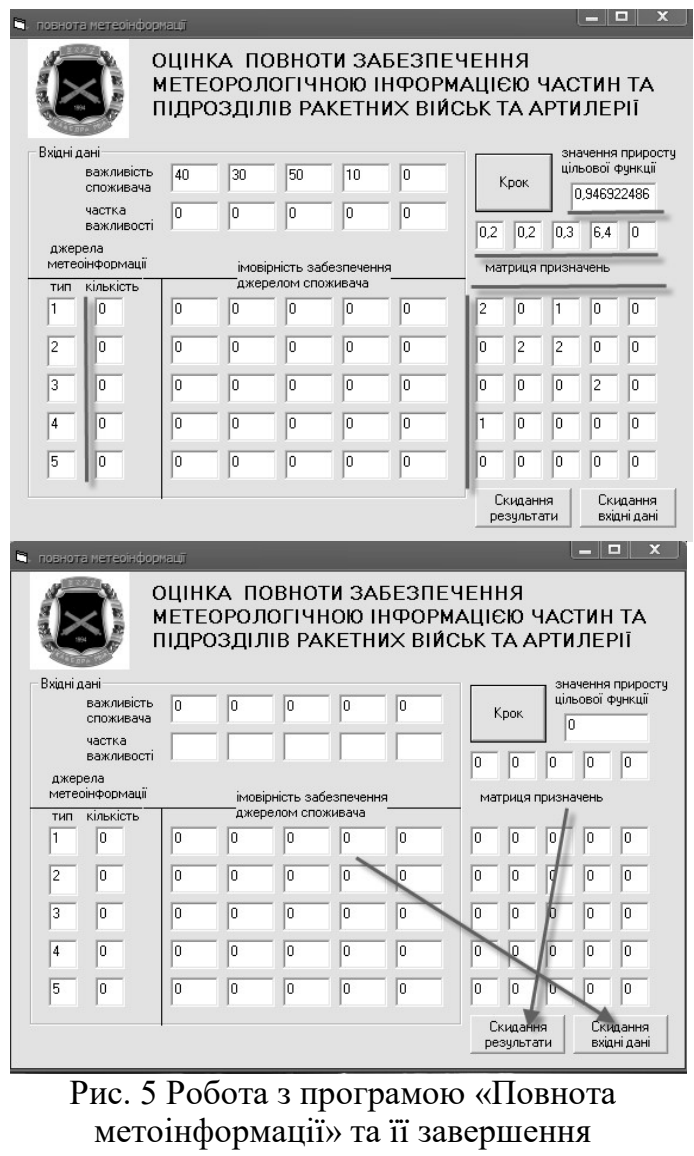

Для корегування вхідних даних та проведення повторних розрахунків необхідно натиснути кнопку «Скидання результати» (рис. 5).

\section{Лimepamypa}

1. Шуляков С.О., Бзот В.Б., Жилін С.І., Шигімага Н.В., Артеменко А.А. Шляхи удосконалення розвідувального забезпечення бойового застосування ракетних військ i артилерії. Збірник наукових працьь Харківського

\section{Висновки і перспективи подальших досліджень}

Таким чином, у статті проаналізовано існуючі форми подачі метеорологічної інформації. Виявлено, що форми подачі такої інформації залежать від під потреб споживача, однак мають частину інформації, яка корисна для потреб військових споживачів, зокрема для потреб РВіA. До такої інформації належать: температура повітря, атмосферний тиск, швидкість і напрямок вітру, вологість повітря. Це дозволило узагальнити форми та визначити корисність кожної форми для потреб певного споживача метеоінформації.

Також, у роботі розроблено порядок переводу метеорологічної інформації отриманої 3 різних джерел у формі КН-01, КН-04, METAR (SPECI) у форму потрібну для військових формувань. Основними етапами порядку $є$ : переведення величини атмосферного тиску; побудова графіку вертикального розподілу стандартних ізобаричних поверхонь та переведення цього графіку 3 стандартних ізобаричних поверхонь до стандартних висот прийнятих в $\mathrm{PBiA;} \mathrm{побудова}$ графіків залежності величин температури повітря, напряму та швидкості вітру від стандартних висот; перерахунок напряму та швидкості вітру в балістичні складові вітру по стандартним висотам; врахування прогнозованих величин метеоелементів; узагальнення метеорологічних та гідрологічних явищ. Зазначений порядок дозволяє використовувати різні форми подачі метеоінформації для потреб $\mathrm{PBiA}$ та надає можливість відповідним органам військового управління оперувати більш широким спектром метеоінформації.

До того ж, у статті розроблено методику оптимального розподілу джерел метеорологічної інформації за споживачами. Сутність методики полягає у застосуванні методу нелінійного програмування, так званого методу двох функцій, для розподілу неоднорідних, за можливостями, джерел метеоінформації між неоднорідними, за потребами, споживачів такої інформації. Ця методика дозволяє оперативно здійснювати розподіл наявних джерел метеоінформації між споживачами такої інформації.

Ще у дослідженні запропонована процедура застосування програмного засобу «Повнота метеоінформації» під час підготовки та бойового застосування відповідними органами військового управління. Ця процедура включає послідовність дій та їх змістовне наповнення щодо застосування зазначеного програмного засобу. Вказана процедура дозволяє зменшити час на засвоєння навичок роботи з вказаним програмним засобом.

Подальші дослідження планується спрямувати на дослідженні доцільності інтеграції програмного засобу «Повнота метеоінформації» до автоматизованої системи управління військами «Славутич».

національного університету Повітряних Сил. 2020. № 1(63). C. 22-30. https://doi.org/10.30748/zhups.2020.63.03 2. Majstrenko O. V., Prokopenko V. V., Makeev V. I., Ivanyk E. G. Analytical methods of calculation of powered 
and passive trajectory of reactive and rocket-assisted projectiles.Radio Electronics Computer Science Control. 2020. № 2. C. 173-182. https://doi.org/10.15588/16073274-2020-2-18. 3. Комплекс радіозондування багатофункціональний Радіотеодоліт-УЛ. Техприлад: веб-сайт.

URL:

http://techprulad.lviv.ua/index.php/ua/vyhotovliaiem/aerolo g-pril. 4. Майстренко О. В., Бубенщиков Р. В., Стеців С. В. Застосування засобів імітаційного моделювання у процесі підготовки майбутніх офіцерів Збройних Сил України до виконання службових обов'язків. Information Technologies and Teaching Aids. 2020. №75(1). C. 186201. https://doi.org/10.33407/itlt.v75i1.2676.

5. Майстренко О. В. Застосування програмного середовища Milchat у військовій освіті з урахування особливостей пандемії. Information Technologies and Teaching Aids. 2021. №84(4). C. 186-201. 6. Дашко Н. А. Курс лекций по синоптической метеорологи. Studfiles: веб-сайт. URL: https://studfile.net/preview/5866303/ (дата звернення: 01.07.2021). 7. Как расшифровать авиационные метео сообщения. Superjet: веб-сайт. URL: http://superjet.wikidot.com/wiki:meteo (дата звернення: 01.07.2021). 8. Авер'янова Ю. Методологічні засади метеорологічного забезпечення аеронавігації використанням поляриметричних засобів дистанційного зондування: дис. доктора технічних наук: $Н A У$, Київ, 2017. 9. Климченко В. Й., Камалтинов Г. Г., Місайлов В. Л. Аналіз потенційних можливостей оглядових РЛС сантиметрового діапазону хвиль щодо забезпечення дій авіації Повітряних Сил Збройних Сил України метеорологічною інформацією. Системи озброєння $i$ військова техніка. 2011. №1. С. 21-27. 10. СемергейЧумаченко А. Б. Застосування критеріїв компетентності авіаційного метеорологічного персоналу до викладання авіаційної метеорології. Управління якістю підготовки фахівиів: на Всеукраїнській наук.метод. конф., 26-27 березня 2019 р. Київ, 2019. С. 152154. 11. Авер'янова Ю. А. Інтерактивна глобальна мережа отримання, обміну та поширення метеорологічних даних. Вісник Начіонального авіаиійного університету. 2012. № 53(4). С. 26-30. https://doi.org/10.18372/2306-1472.53.3481. 12 Авер'янова Ю. А., Яновський І. Ф. Динамічна складова глобальної інтерактивної мережі одержання та обміну метеорологічними даними. Вісник Національного Авіачійного Університету. 2011. № 49(4). С. 36-41. https://doi.org/10.18372/2306-1472.49.78.

Трофименко П. Є., Макєєв В. І., Раскошний А. Ф. Оцінка точності урахування метеорологічних факторів при стрільбі на великі дальності. Системи озброєння $i$ військова техніка. 2010. № 3(23). С. 85-89. 14. Васильсв В. М., Харченко В. П. Моделювання аеронавігаційних систем. Оброблення інформації та прийняття рішень в системі керування повітряним рухом: навч. посіб. Київ : НАУ, 2008. 180 с. 15. Атаманський Д. В. Перспективна мережа радіолокаційних засобів метеорологічного обслуговування авіації. Збірник наукових праць Харківського національного університету Повітряних Сил. 2018. № 3. С. 92-102. URL: http://nbuv.gov.ua/UJRN/ZKhUPS $2018 \quad 3 \quad 16 . \quad 16$. Юрчук Л. Ю., Родінін О. В. Спеціалізована система збирання та обробки інформації для метеорологічного моніторингу. Вісник Вінницького політехнічного iнституту. 2013. № 1. C. 18-22. URL: https://visnyk.vntu.edu.ua/index.php/visnyk/article/view/111 7. 17. Пилипович Г. Г., Шевченко В. Л., Дровнін А. С., Мусін Р. Р., Олійник О. Л. Оптимізація роботи чергового метеоролога із використанням автоматизованого робочого місця синоптика. Сучасні інформаиійні технологї у сфері безпеки та оборони. 2014. № 2(20). C. 80-87. 18. Машков О. А., Мусін Р. Р., Пилипович Г. Г. Оптимізація роботи чергового метеоролога із використанням автоматизованого робочого місця синоптика. Системи управління, навігачї та зв'язку. 2015. № 3. С. 95-97. 19. Дорошенко А., Томишин Ю., Яценко О. Проектування програми метеорологічного прогнозування для багатоядерної платформи. Winter infocom advanced solutions. 2018. C. 55-56. URL:

https://iconfs.net/uploads/w.infocom2018/zbirnik-winter-

infocom-2018.pdf. 20. Майстренко О., Франчук Ю. Використання інтерактивних технологій в системі формування вмінь у майбутніх офіцерів служби ракетно-артилерійського озброєння. Збірник наукових прачь Наџіональної академії Державної прикордонної служби України. Серія: педагогічні науки. 2019. №19(4). C. 227-238. https://doi.org/10.32453/pedzbirnyk.v19i4.269. 21. Жалдак М. І., Триус Ю. В. Основи теорії і методів оптимізації : навчальний посібник. Черкаси : БрамаУкраїна, $2005 . \quad 608$ c. URL: https://chtyvo.org.ua/authors/Zhaldak Myroslav/Osnovy te orii i metodiv optymizatsii/. 22. Берзин Е. A. Оптимальное распределение ресурсов и элементы синтеза систем. Москва: Сов. Радио, 1974. 304 с. URL: https://opac.lviv.ua/bib/607539. 23. Основи моделювання бойових дій військ: підручник. Київ : НАОУ, 2005. 481 c. URL: https://elib.nuou.org.ua/katalog/osnovymodeluvannya.html. 24. G. Fontenot, E. J. Degen, D. Tohn. On Point: The United States Army in Operation Iraqi Freedom. Fort Belvoir, Virgini : CreateSpace Independent $\begin{array}{llll}\text { Publishing } \quad \text { Platform, } 2012 . & 594 & \text { p. }\end{array}$ URL: https://apps.dtic.mil/dtic/tr/fulltext/u2/a524388.pdf.

25. A. Feickert. U.S. military operations in the global war on terrorism : Afghanistan, Africa, the Philippines, and Colombia. Репозиторий Dspace, 2005. 25 p. URL: http://afghandata.org:8080/xmlui/handle/azu/4110.

26. N. Roman, W. Wanta, I. Buniak. Information wars: Eastern Ukraine military conflict coverage in the Russian, Ukrainian and U.S. newscasts. International Communication Gazette. 2017. №79(4). P. 357-378. https://doi.org/10.1177/1748048516682138. 27. O. Jonsson, Russian Full-Spectrum Conflict: An Appraisal After Ukraine. The Journal of Slavic Military Studies. 2015. № 28(1). P.

$1-22$. https://doi.org/10.1080/13518046.2015.998118. 28. J. Lyall. Does Indiscriminate Violence Incite Insurgent Attacks?: Evidence from Chechnya. Journal of Conflict Resolution. 2009 . №53(3). P. 331-362. https://doi.org/10.1177/0022002708330881. 29. J. Nichol. Russia-Georgia Conflict in August 2008: Context and Implications for U.S. Interests. Fort Belvoir, Virgini: Defense technical information center, 2009. 40 p. URL: https://apps.dtic.mil/dtic/tr/fulltext/u2/a496306.pdf. 30. Тактична підготовка артилерійських підрозділів: підручник / Трофименко П. Є., Пушкарьов Ю. І., Латін С. П. та ін. Суми : Сумський державний університет, $2012 . \quad 776 \quad$ c. http://essuir.sumdu.edu.ua/handle/123456789/30163. 31. Заболотников Г. В. Учебное пособие по работе с кодом метеорологической информации КН-04:Учебное пособие. С.-П.: РГГМУ, 2010. 35 с. 32. Novotny J., Dejmal K., Repal V., Gera M., Sladek D. Assessment of TAF, METAR, and SPECI Reports Based on ICAO ANNEX 3 Regulation. Atmosphere. 2021. №12(2). 138 p. https://doi.org/10.3390/atmos12020138. 33. Заболотников Г. В. Учебное пособие по работе с кодом метеорологической информации КН-01: Учебное пособие. С.-П.: РГГМУ, $2010 . \quad 42 \mathrm{c}$ URL: https://www.studmed.ru/zabolotnikov-g-v-uchebnoeposobie-po-rabote-s-kodami-meteorologicheskoyinformacii-kn-01 ebd988d40f0.html. 34. Popov V. N., Botygin I. A., Kolochev A. S. Software for storage and processing coded messages for the international exchange of meteorological information. In Journal of Physics: Conference Series. 2017. №803(1). 6 p. https://doi.org/10.1088/1742-6596/803/1/012122. 

РАКЕТНЫХ ВОЙСК И АРТИЛЛЕРИИ

\author{
Александр Васильевич Майстренко (доктор военных наук) \\ Александр Викторович Лихолёт \\ Максим Александрович Кольченко
}

\author{
Национальный университет обороны Украины имени Ивана Черняховского, Киев, Украина
}

\begin{abstract}
Исследование посвящено обоснованию подходов по разработке и внедрению программы связанной с определением потребности в средствах метеорологического обеспечения $u$ полноть метеорологической информации в соответствующих воинских формированиях.

В статье проанализированы существующие формы подачи метеорологической информации. Выявлено, что формы подачи такой информации зависят от потребностей потребителя, однако имеют часть информации, которая полезна для нужд военных потребителей, в частности для нужд ракетных войск и артиллерии. К такой информации относятся: температура воздуха, атмосферное давление, скорость и направление ветра, влажность воздуха.

Также, в работе разработан порядок перевода метеорологической информаџии полученной из различных источников в форму необходимую для воинских формирований. Основными этапами порядка являются: перевод величины атмосферного давления; построение графика вертикального распределения стандартных изобарических поверхностей и перевода этого графика со стандартных изобарических поверхностей к стандартным высотам принятылм в ракетных войсках и артиллерии; построение графиков зависимости величин температуры воздуха, направления и скорости ветра от стандартных высот; пересчет направления и скорости ветра в баллистические составляющие ветра по стандартным высотам; учет прогнозируемых величин метеоэлементов; обобщение
\end{abstract} метеорологических и гидрологических явлений.

K тому же, в статье разработана методика оптимального распределения источников метеорологической информации по потребителям. Сущчность методики заключается в применении метода нелинейного программирования, так называемого метода двух функиий, для распределения неоднородных, по возможностям, источников метеоинформачии между неоднородныли, по потребностям, потребителями такой информации. Эта методика позволяет оперативно осуществлять распределение имеющихся источников метеоинформации между потребителями такой информации.

Еще в исследовании предложена прочедура применения программного средства «Полнота метеоинформации». Эта проиедура включает последовательность действий и их содержательное наполнение по применению указанного программного средства. Указанная прочедура позволяет уменьшить время на усвоение навыков работь с указанным программным средством

Ключевые слова: метеорологическая информация, оптимальное распределение, программное средство, подготовка войск.

\title{
APPLICATION OF THE METHOD OF TWO FUNCTIONS FOR SOLVING THE TASKS OF COMBAT SUPPORT OF MISSILE TROOPS AND ARTILLERY
}

\author{
Oleksandr Maistrenko (Doctor of Military Sciences) \\ Oleksandr Lykholot \\ Maksym Kolchenko
}

\section{The National Defence University of Ukraine named after Ivan Cherniakhovskyi, Kyiv, Ukraine}

The study is devoted to the substantiation of approaches to the development and implementation of a program related to determining the need for meteorological equipment and the completeness of meteorological information in the respective military formations.

The article analyzes the existing forms of meteorological information. It was found that the forms of providing such information depend on the needs of the consumer, but have some information that is useful for the needs of military consumers, in particular for the needs of missile troops and artillery. Such information includes: air temperature, atmospheric pressure, wind speed and direction, humidity.

Also, the paper develops the procedure for translating metrological information obtained from various sources into the form required for military formations. The main stages of the order are: transfer of atmospheric pressure; construction of a graph of vertical distribution of standard isobaric surfaces and transfer of this graph from standard isobaric surfaces to standard heights accepted in missile troops and artillery; plotting the dependence of air temperature, direction and wind speed on standard heights; recalculation of wind direction and speed into ballistic wind components at standard heights; taking into account the predicted values of meteorological elements; generalization of meteorological and hydrological phenomena.

In addition, the article develops a method of optimal distribution of sources of meteorological information by consumers. The essence of the method is to apply the method of nonlinear programming, the socalled method of two functions, for the distribution of inhomogeneous, if possible, sources of metadata between 
inhomogeneous, as needed, consumers of such information. This technique allows to quickly distribute the available sources of meteorological information among consumers of such information.

The study also proposed a procedure for using the software "Completeness of meteorological information". This procedure includes a sequence of actions and their content for the use of the specified software. The specified procedure allows to reduce time for mastering of skills of work with the specified software.

Key words: meteorological information, optimal distribution, software, training of troops.

\section{References}

1. Shuliakov Serhii, Bzot Volodymyr, Zhylin Yevhenii, Shigimaga Natalia, Artemenko Artem. Ways to Improve the Intelligence Support of Rocket Troops and Artillery Combat Use. Scientific Works of Kharkiv National Air Force University. 2020. № 1(63). P. 22-30. 2. Majstrenko O. V., Prokopenko V. V., Makeev V. I., Ivanyk E. G. Analytical methods of calculation of powered and passive trajectory of reactive and rocket-assisted projectiles.Radio Electronics Computer Science Control. 2020. № 2. P. 173-182. 3. Multifunction radio sounding complex Radio TheodoliteUL. Techdevice: website. 4. Maistrenko O. V., Bubenshchikov R. V., Stetsiv S. V. Application of simulation modeling means in the process of training future officers of the Armed Forces of Ukraine for performance of officials. Information Technologies and Teaching Aids. 2020. №75(1). P. 186-201. 5. Maistrenko O. V. Application of the Milchat software environment in military education, taking into account the specifics of the pandemic. Information Technologies and Teaching Aids. 2021. №84(4). P. 186-201. 6. Dashko N. A. Lecture course on synoptic eteorology. Studfiles: веб-сайт. 7. How to decrypt aviation meteorological messages. Superjet: website. 8. Averyanova J. A. Methodological bases of meteorological support of air navigation with the use of polarimetric means of remote sensing: dis... Dr. Tech. Sciences: Nat. aviation. un-t, Kyiv, 2017. 9. Klimchenko V. J., Kamaltynov G. G., Misaylov V. L. Analysis of potential observation radar centimeter wavelength range to ensure action aircraft Air Force meteorological information Ukraine. Weapons Systems And Military Equipment. 2011. №1. P. 21-27. 10. SemergeiChumachenko A. B. Application of aviation meteorological personnel ompetence criteria to the teaching of aviation meteorology. Quality management of training: AllUkrainian scientific-methodical conference, March 26 - 27, 2019. Kyiv, 2019. P. 152-154. 11. Averyanova J. A. Interactive global network for weather data obtaining, exchange and dissemination. Proceedings of the National Aviation University. 2012. № 53(4). P. 26-30. 12. Averyanova J. A., Janowski I. F. The dynamic component of the global interactive network for weather data obtaining and dissemination.. Proceedings of the National Aviation University. 2011. № 49(4). P. 36-41. 13. Trophimenko P. E., Makeev V. I., Raskochniy A. F. Accuracy assessment account meteorological factors firing for long range. Systems of Arms and Military Equipment. 2010. № 3(23). P. 85-89. 14. Vasil'ev V. M., Kharchenko V. P. Modeling of aeronavigatsynyh systems of protecting information that take rishen at the system keruvanna we will take room: Navch. posib. Kyiv : NAU, 2008. 180 p. 15. Atamansky D. V. Perspective network of radar means of meteorological service of aviation. Collection of scientific works of Kharkiv National University of the Air Force. 2018. № 3. P. 92-102. 16. Yurchuk L. Yu., Rodinin O. V. Specialized system of collection and processing of information for meteorological monitoring. Visnyk VPI. 2013. № 1. P. 18-22. 17. Pylypovych H. H., Shevchenko V.
L., Drovnin A. S., Musin R. R., Oliinyk O. L. Optimization of duty meteorologist work using forecaster automated workstation. Modern Information Technologies in the Sphere of Security and Defence. 2014. № 2(20). P. 80-87. 18. Mashkov O. A. Optimization of work of the next meteorologist with use of the automated workplace of the weather forecaster. Systems of management, navigation and communication. 2015. № 3. P. 95-97. 19. Doroshenko A., Tomishin Yu., Yatsenko O. Designing a meteorological forecasting program for a multi-core platform. Winter infocom advanced solutions. 2018. P. 55-56. 20. Maistrenko O., Franchuk Yu. Use of interactive technologies in the system of formation of skills in future officers of the rocket and artillery weapon service. Collection of scientific works of the National Academy of the State Border Guard Service of Ukraine. Series: Pedagogical Sciences. 2019. №19(4). P. 227-238._21. Zhaldak M. I., Trius Yu. V. Fundamentals of Theory and Methods of Optimization: Navch. posib. Cherkasy : Brama-Ukraine, 2005. 608 p. 22. Berzin E. A. Optimal resource allocation and elements of systems synthesis. Moscow: Sov. Radio, 1974. 304 p. 23. Basics of modeling military operations: Textbook. Kyiv : NDAU, 2005. 481 p. 24. G. Fontenot, E. J. Degen, D. Tohn. On Point: The United States Army in Operation Iraqi Freedom. Fort Belvoir, Virgini : CreateSpace Independent Publishing Platform, 2012. 594 p. 25. A. Feickert. U.S. military operations in the global war on terrorism : Afghanistan, Africa, the Philippines, and Colombia. Репозиторий Dspace, 2005. 25 p. 26. N. Roman, W. Wanta, I. Buniak. Information wars: Eastern Ukraine military conflict coverage in the Russian, Ukrainian and U.S. newscasts. International Communication Gazette. 2017. №79(4). P. 357-378. 27. O. Jonsson, Russian Full-Spectrum Conflict: An Appraisal After Ukraine. The Journal of Slavic Military Studies. 2015. № 28(1). P. 1-22. 28. J. Lyall. Does Indiscriminate Violence Incite Insurgent Attacks?: Evidence from Chechnya. Journal of Conflict Resolution. 2009. №53(3). P. 331-362. 29. J. Nichol. Russia-Georgia Conflict in August 2008: Context and Implications for U.S. Interests. Fort Belvoir, Virgini: Defense technical information center, 2009. 40 p. 30. Tactical training of artillery units: textbook / Trofimenko P. E., Pushkarev Yu. I., Latin S. P., Lyapa N. N. and other. Sumy : Sumy State University, 2012. 776 p. 31. Zabolotnikov G. V. Textbook for working with the code of meteorological information KN-04: textbook. S.-P.: RGGMU, 2010. 35 p. 32. Novotny J., Dejmal K., Repal V., Gera M., Sladek D. Assessment of TAF, METAR, and SPECI Reports Based on ICAO ANNEX 3 Regulation. Atmosphere. 2021. №12(2). 138 p. 33. Zabolotnikov G. V. KH-01 Meteorological Codes Tutorial: textbook. S.-P.: RGgMU, 2010. 42 p. 34. Popov V. N., Botygin I. A., Kolochev A. S. Software for storage and processing coded messages for the international exchange of meteorological information. In Journal of Physics: Conference Series. 2017. №803(1). 6 p. 